\title{
Rabbi Abraham Joshua Heschel's religious antecedents as legitimising a Christian faith expression
}

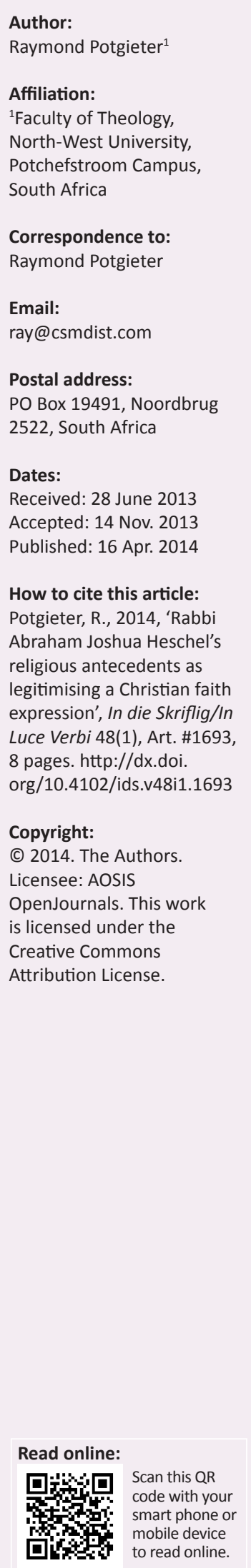

Rabbi Abraham Joshua Heschel's depth theology model is a theology of the act of believing. It emerges from the Chasidic expression of Judaism founded during the Enlightenment period. A modern approach is to profile God according to circumstances as a prerequisite to believing. The uniqueness of this Jewish concept of faith is come to in an indirect way. Heschel argues from antecedents to believing in order to establish faith's credibility. This is done, not by emphasising content of belief in the first instance, but on awareness of reality at its fullest expression. This approach could be seriously considered as establishing grounds towards credible Christian faith expressing a living testimony. It could also serve as an ecumenical bridge between Jewish and Christian religions in their sharing of commonalities of the basics of what constitutes legitimate faith.

Rabbi Abraham Joshua Heschel se godsdienstige geskiedenis ter regverdiging van 'n uitdrukking (ervaring) van die Christelike geloof. Rabbi Abraham Joshua Heschel se diepteteologie model is ' $n$ teologie van die daadwerklikheid van geloof. Dit blyk uit die Chasidiese uitdrukking van Judaïsme en is tydens die Verligtingstydperk gegrondves. 'n Moderne teïstiese benadering is om ' $n$ profiel van God volgens omstandighede as voorvereiste van geloof te skep. Die uniekheid van dié Joodse konsep van geloof kom op indirekte wyse. Heschel redeneer vanuit sy religieuse (voor)geskiedenis ter vasstelling van die geloofwaardigheid van die Christelike geloof. Dit word gedoen deur in die eerste plek nie die inhoud van geloof te beklemtoon nie, maar wel 'n bewustheid van die werklikheid as die volste uitdrukking daarvan. Hierdie benadering kan ernstig oorweeg word as die vestiging van 'n geloofwaardige Christelike geloofsuitdrukking as lewende getuienis. Dit kan ook as ekumeniese brug tussen die Joodse en Christelike godsdienste dien in die gedeelde raakpunte wat geloof regverdig.

\section{The winds of change}

The age of Enlightenment originated about 1650-1700 and demonstrated the diminishing hope of doctrinal unity amongst Protestants and Roman Catholics. A consequence was the focus of attention upon secular learning, in particular mathematics and science, marking an advance unparalleled since the Greeks (Russell 1945:525). During this time another movement termed the Jewish Enlightenment began. It explored the new freedoms possible through reason, primarily through the works of Mendelssohn, Lessing and Lavator (1971), which paved the way for the later notions of Schiller, Kant and Goethe (Jospe 1971). The winds of change had come for Judaism (Hajdu \& Mazor 1971). But it had also come for religion in general in the third millennium. In his prolegomena, Schellenberg (2005:37) identifies the ultimate ${ }^{1}$ in religion as a reality in relation to which an ultimate good can be attained in all religions present or still in embryonic form. Janz (2004), on the other hand, develops a modified Kantian space to claim penultimate reality for Christianity (Potgieter 2013b).

Early in this Enlightenment period, Baruch Spinoza (AD ${ }^{2}$ 1632-1677) from the Netherlands, questioned cardinal Jewish beliefs and finally concluded with a pantheist deity. Another great Jewish scholar from Poland, also questioned the traditional expression of his Jewish faith. Rabbi Yisroel ben Eliezer, also known as Baal Shem Tov (AD 1700-1760), is considered the founder of Chasidic Judaism (Scholem 1971). This must not be confused with the Chasidim of the 2nd century BC (Cross 1977:271). Reacting to an overly academic approach to the Jewish faith, the Baal Shem began emphasising divine presence expressed with joy and enacted spirituality as a way of life. The Baal Shem together with Menachem Mendel (AD 1787-1859), also known as the Kotzker or the Kotzker Rebbe (Rubinstein 1971:1050-1058), had major influence on Rabbi Abraham Joshua Heschel (AD 1907-1972). 
Heschel wrestled with the tension of polar opposites implicit in the teachings of these great rabbis (Friedman 1976:6768). Whilst the Baal Shem delighted in God's immanent presence, the Kotzker's theology could produce no solid basis to find God anywhere. According to Green (1997), discovery of truth results in ecstatic passion - this is a far cry from the impervious god of the philosophers. ${ }^{3}$ Religion is not eclipsed in society rather it would be responsible for its own demise, especially when ultimate questions are not asked and answered (Heschel 1972b:3). These historic tensions caused an oscillation between degrees of emphases: now upon presence and love; now upon truth and absence. Both couched in emotional and not sterile expression. Faith is never completely replaced by creed (Heschel ibid:3), or put differently by Smith (1963:1): 'Sensitive men have ever known that they are dealing with a mystery.' Such a varied degree of appreciation of life continued to be a lifelong challenge for Heschel (Merkle 1985:5). Sometimes the appeal would be to the heart and at other times to the mind. So much so that he maintained this polarity in tension as a principle for his own religious development (Merkle ibid:6) - to develop the awe he had for the spiritual in what Friedman (1976:65) called 'devotional philosophy'.

Heschel's writings reveal this tension expressed in terms of degrees of immanence and of transcendence of God: it was creedal and passionate, the one never subsuming the other. This caused him to explore the gap in the middle when these concepts are ideally juxtaposed. In the Baal Shem Tov's expression of God, there is the concept of deity involved with creation and in particular with this world. The Kotzker comes from a more pessimistic perspective and God's seeming absence served to explain the misery on earth. It was this latter view that Heschel (cited by Merkle 1985:xiv) met with when considering the horrors of Auschwitz.

Heschel's theology entered into the vacuum between the polar opposites of deity's presence and absence (immanence and transcendence), ${ }^{4}$ and provided a bridge from religion to reason and living. One form of his theological expression was expressing faith in credible academic fashion as the bipolar composite of process and content, or an act of faith together with its content.

\section{Exploring faith's origins in God}

Hartman (1997:2) points out that Heschel deliberately emphasised God in anthropomorphic terms ${ }^{5}$ in contrast to the approach of depicting God as living reality. He also did

3.Aristotle's impassable deity being too sublime for even a relation to proximity. There is no thought of considering that it might have heart or care about the creation divinely set in motion. This is not the God of the Hebrew prophets (cf. the Song of Moses, Ex 15:1-18; Dt 32:1-43) involved with his people. However, in my opinion Heschel does not fall into the trap of soft panentheism (Potgieter 2013b). This is not the opinion of Friedman (1976:69) who sees a unification of God and the world in Heschel's work, suggesting that transcendent God is ever straining to unite with immanent God. This tension is obviated by the strong emphasis on monotheism by Heschel (cf. 1962).

4. Heschel (cf. 1972b:4) is conscious of the tensions with theology and philosophy.

5.Cohen (1908:vii) states that 'Anthropomorphism is inseparable from Religion', and suffices for its utilitarian use as a means to an end. His own work avoided such a resort on the basis of a rational approach. not want to lose sight of God through obscuring deity with a normative halakhah [Jewish law as way of life] expressing commitment to behaviour. Whilst Heschel does represent a Chasidic tradition, his faith represents both rational and mystic expressions. He expounds his particular insights by way of depth theology - a method by which he explores the origins and sources of religious faith as self-clarifying and self-examining (Heschel 1972b:8). This is significant. The reason being that Heschel, on the one hand, does so rationally (Friedman 1976:66) - exploring the sense of wonder, an experience shared variously by individuals and humankind - as opposed to a fundamentalist concept of faith reliant upon communal creedal expression. Cherished beliefs are subjected to rational scrutiny allowing the emergence of those elements that uniquely identify faith. Coming from a Jewish tradition, its logical expression is an identification with Judaism. Because of this rational approach he is open to peer review, and favourable reviews and publications established him as a scholar of note. Whilst his personal persuasion always was a matter of choice for him, he also acknowledged that faith expresses itself variously, including the subjective, an awareness of the ineffable (Friedman ibid:68). ${ }^{6}$ Bringing these two dimensions together ${ }^{7}$ reveals that they commonly share faith and that Judaism expresses itself as one of many religions. To identify the emergence of faith, religions commonly share universal antecedents, which finally define and peculiarly orientate faith as an act of believing.

Tertullian's rhetorical question, 'What has Jerusalem to do with Athens?' may be applied here in that Christianity shares the act of believing with Judaism - as both indeed share it with other religions. Theology traditionally has a narrower horizon than religion in the Christian context and tends to lean towards a system of beliefs to express Christian living. Berkhof (1873-1957; 1979:36-37) says that it arises out of a believing community to become its property. The Bible, however, teaches a revelation of God. Whilst Heschel will agree with Guthrie (1981:29) up to this point, the latter then passes over to revelation, rejecting humankind's variety of religious experiences. A religious seeker is immediately transported to an all (read the Bible for truth) or nothing approach. Heschel questions this approach. For it is precisely within these rational and subjective experiences that the literate or illiterate, evangelised or non-evangelised, Jew, Christian or Muslim explore their gifts of rationality and experience emotions that eventually lead to the transcendent beyond. Heschel identifies antecedents that serve as signposts along this journey of living faith.

This article will explore the richness of the antecedent components identified by Rabbi Heschel. It will seek to apply these particularly to the Christian perspective of the experiential act of belief in God.

6. Implying that transcendence ought to be understood as suggestive of 'reality which gives certainty without knowledge' (Friedman 1976:68).

7.'God and man need one another' (Cohen 1908:9). 


\section{An introduction to believing}

Heschel's book, Man is not alone (1972a), was highly acclaimed at the time of its publication. So much so that Reinhold Niebuhr said foresightedly that Heschel would become an authoritative and commanding voice in both the Jewish and Christian communities as well as in American religious life (Kirkus 2012). The content of the rabbi's books is not easily arranged. He wrote and demonstrated against the Vietnam War, questioning the implication of the rebirth of the Jewish state with farsighted commentary (Hartman 1997:1). His theological thoughts do not fit into traditional theological structure, but seem to follow the theme of God in relationship with humankind and humankind in relationship with God. To that end, the search for God is initiated by an awareness of transcendency, finally concluding with faith as a way of life and the act of believing.

John C. Merkle (1985) and Fritz A. Rothschild (1965) systematised the thoughts of Rabbi Heschel into substantive categories. These significant insights could only come from scholars immersed in Heschel's depth theology and serve to plumb its profundity. This article does not actively pursue a philosophy of religion approach. Rather, it is theological by nature, written from a Christian perspective and employs the aforementioned when deemed applicable. A theocentric perspective of the centrality of God as a living reality, together with halakhic commitment (Hartman 1997:2), become a reflection of life with God. Although there are clearly many Jewish distinctives that elaborate upon Heschel's dealing with antecedents, enriching his pursuit in developing his theology, these cannot be touched upon here.

Belief and faith engaged Heschel (1962) from the beginning of his academic career. Illustrative of Heschel's insights, questioning traditional perspectives of belief is his treatment of the prophets. Prophets, he contends, are not divorced from prophecy. They are in the first instance human beings and secondly those who rejected societies evils. Their prophecies validate what happened to them and in them (Heschel ibid:xix; cursive in the original). Whilst prophecy may have run its course, the person of the prophet remains. One must retain something of the prophet's attitude to hear God's voice in every generation. Humankind needs the prophets to enliven its faith and belief in every generation. It will become clear from this article, however, that Heschel (Rothschild 1965:245) also held that the recorded words of Scripture render but one of a myriad of possible scenarios. Yet, the present words comprise what God wanted humankind to know - its use is to feel the need for sanctification (Rothschild ibid:249-250), and also for a sanctified life preparing the way for Messiah. Life reflects humankind's image: that of God's presence or that of beast (Rothschild ibid:257).

Humankind's relationship to God is, however, complex for it takes reality into consideration. Faith expresses itself in every relationship - being alive in the moment, the encounter with God, to tradition and the spiritual journey (Friedman 1976:69). Key to this relationship is Heschel's encapsulating of the variety of meanings of pathos (Heschel 1962:489-492; 1972a:244-245) as revealing the extreme pertinence of man to God (Heschel 1962:483, cf. 489-492). Buttressing this statement is his understanding of humankind assisting God's involvement in history, which reveals a side of pathos: humankind's proximity to God. Persons become aware of transcendent and immanent God's divine secret - his concern for and involvement in humankind and this world - whilst God's message is conveyed through the prophets and they consequently experience God's response in varying degrees of concern (such as mercy, anger, benevolence etc.), explaining involvement and detachment from this world (Heschel 1962:483). Being subject to God's vision and cognisant of his concern for humankind reveals the thoughts of God (Heschel 1962:488). This approach to the divine is not necessarily unique to Judaism - it is common religious experience and so also pertinent to Christianity (Hartman 1997:3). Above all, however, the point is that it is a faith experience accompanied by reasoned acceptance (cf. Smith 1963:195). What makes it unique is Heschel's insight that humankind responds to the divine upon divinity's terms. Humankind must know itself, and know God - the one without the other leads to a misplaced faith and futile faith process. Exploring this leads to the emergence of depth theology as means for exploring faith's particular subjectivity and its emergent expression.

\section{Depth theology}

Depth is understood variously. It is used to analytically explore connections and ties between what is known. This is done through probing personal opinions, beliefs and values through a method called 'Depth interview' (Wikipedia n.d.). On the other hand, Breslow's depth (Breslow 1970) is a prognostic tool describing the depth of invasion of tumour cells of a melanoma. Peter O'Leary's poetry in Depth Theology (2006) explores the elusiveness of the hidden God of religious knowledge. He does so coming from a Christian emphasis, using depth psychology to bridge the conscious and unconscious worlds for the spiritual seeker (O'Leary ibid:57).

Theology serves to qualify Heschel's use of depth. Classically, it deals with beliefs and defines dogmas and is the stuff of creeds. Whilst this systematisation of faith is useful, it must never lose sight of its connection to the dynamic expression of faith. That implies that a living theology is therefore a living relationship between creed and religious living (Merkle 1985:50). This is where theology emerges. Its dynamic insights bring the two together and so religious experience serves as the source of theology (think of the prophets and humankind confronted with creation). Theology is the consequence of insights that emanate from that encounter (Merkle ibid:50). For Heschel, theology allows for divergent personal commitment to a particular faith or religious tradition and the possibility for ecumenical dialogue (Kasimov 1981:423, 430). ${ }^{8}$

8.Kasimov (1981:425) states that this view contrasts with those Jews who hold that Judaism is the only true expression of religion, rejecting for instance key Christian doctrines such as the deity of Christ. 
Heschel merges depth and theology in a particular way. Basically, it is an attempt to address the subjectivity and disconnectedness of encounters with reality (Heschel 1972a:20) with the premise of paradox (Heschel 1962:209). Added to that, it faces the question of how to communicate such encounters. To illustrate: great works of art, the classics and great music, for instance often leave one with the feeling that, though profoundly sublime, more could have been communicated and so it gives a sense of incompleteness. This inadequacy is not to be confused with C.S. Lewis' (1955) primary sense of longing. That was an intense desire, a longing for something which he perceived as joy, and intuitively knew that it would never be fully realised in this life. Heschel on the other hand saw God's presence everywhere, but acknowledged that humankind experiences resistance in perceiving the message of reality (Heschel 1972a:20). The real is often misunderstood - being confused or obscured by concepts, over and understatements. This causes tension, for humankind must understand to believe (Heschel 1972a:296).

This chasm, caused by a polarity of reality and perception, is suggestive of some complexity, but, as developed by Heschel, it is not a realm of the obscure. Implicit in bridging this chasm is establishing the correct relationship with the Creator through insight and understanding, enhancing communication and act. This does not accord with what the Jedi Master Yoda famously said to Luke Skywalker in Star Wars: 'Do, or do not. There is no try' (QuoteDB n.d.). It does, however, illustrate the immensity of the task Heschel set himself. He tried, and Christians may equally benefit from his insights.

More pertinently, depth theology is related to faith in the sense of possibility of movement. As Heschel understood it: '[T] o study the act of faith and its antecedents, to explore the experiences, insights, emotions, attitudes and acts out of which faith arises' (Merkle 1985:50, cf. 218). Heschel makes this clear when he militates against preconceived notions that put the cart before the horse in an analysis of consciousness in particular that of the prophets (Heschel 1962:xiv cf. Merkle ibid:8). 'One is forced to admit that some of the causes and motives of our thinking have led our existence astray, that speculative prosperity is no answer to spiritual bankruptcy' (Heschel ibid:xviii-xix). Admittedly, the context is that of viewing a prophet of God. The same may also be said of any person who wishes answers to problems and is dissatisfied with answers unrelated and irrelevant to them. It was his understanding of the prophets that aided his religious studies. Prophets were persons with preconceived ideas. These were influenced by presuppositions or premises necessitating the prophet to minister within a particular way of thinking that underlies the pathos of prophetic theology (Heschel ibid:xix). Pathos is God's outrage at man's sinfulness leading to suffering and anguish. That is, however, not the full story. Accompanying it is God's merciful response to mankind. Receiving God's message clearly is a point at issue.

To understand the message of God, an adjustment would be necessary as to apprehend how it applies to both original spokesperson and audience. This would lead to recapture the original and new way of thinking, which bring about a connection between real questions and reality (Heschel 1962:xix): a connection that takes place within the conscious experience of the prophet; a movement between levels of the transcendent and immediate. This insight gives a glimpse into the tensions a prophet had to deal with. Translated, it was about what happened to and in the prophet. Heschel perceptively inverts the traditional view of 'though dead the message of the prophet remains' to focus on the person of the prophet. Though prophecy ceased, their enduring witness continues to testify of both transcendent and personal realms.

Extrapolated, this view has some significance for any religious faith reliant upon prophets. Contrasting this approach is Schellenberg (2005:62-64), who separates belief from emotions. In a nutshell, no commitment to a volitional and emotive approach serves as grounds to claim credence for any fundamental statement with assurance. For Heschel this is to miss the point. The message of the person of the prophet is enduring and relevant today. Yet, their holistic message ${ }^{9}$ remains disturbing, for through them the Bible came into being (Heschel 1962:xxi). So much so that what applies to Judaism would be implicit for Christianity and Islam whose roots find some commonality in Judaism. Heschel provides credibility to the suggestion that Judaism, or any other religion for that matter, may distinguish its particular uniqueness from its shared religiousness through reason and experience. Bridging this vacuum is not unique to Judaism or, for that matter, its Chasidic expression alone. Rather, it is a common feature found at ground level of most religious faiths. The bridge that is shared by religions is that of particular faith expressions. However, the journey towards formulating that unique faith expression is Heschel's concern. It is the process of developing a credible faith that occupies him - one which will gradually take systematic and creedal shape, but still continue to reflect the prophet's experience of the transcendent and the immanent immediate. There is no preconceived certainty that anything will lead to a conclusion. It must be an exploration, not an explanation alone, for the subject deals with people seen as whole human beings.

\section{The dynamism of faith}

A prophet experienced God's presence at the immanent level of conscious existence. ${ }^{10}$ The message from God implied the greater purpose of God, regardless of what the prophet personally may have preferred (Heschel 1962:xix). Reconciling humankind to himself overshadowed any personal bias or choice. Humankind's independence, security and pride translating into resentment at God's intrusive involvement in history all serve as crucible for the understanding of faith dependent upon its antecedents (Heschel 1962:xix; Merkle

9. Heschel focuses on the prophet - not solely as the conveyer of divine messages through inspiration. Accompanying the message is the life of the prophet as well, the human situation of dealing with content not issuing from the prophet's mind. A prophet may also be a husband, father, statesman, king, et cetera (Heschel 1962).

10.'The alternative to our Jewish existence is spiritual suicide, disappearance, not conversion into something else' (Heschel 1978:108). 
1985:51). These antecedents bridge the chasm between God and created reality. 'God is a name but no reality' (Heschel 1954:xii, cursive in the original). Cohen (1908:70), on the other hand, is radically sceptical about this view of reality, claiming that humankind can only imitate what it receives from God - a mimetic reflection more evident in a matter such as prayer. In fact, God is the expression of the subjective nature of humankind (Cohen ibid:86).

Faith expression takes place within the real, because it necessitates dependence upon its origins to authenticate it. ${ }^{11}$ Christians often refer to the sacramental view of spiritual relationship, whilst Heschel (1966:133) is more inclusive: divine sparks in our souls, to nurture openness to the spirit of the Psalms, reverence for the words of the prophets, and faithfulness to the living God. Whichever approach is used, however, they express some dynamic tension in the relationship between reason and revelation, leading to a life of faith (Hellwig 1985:xi). For Heschel (Rothschild 1965:69): 'The way to faith is the way of faith.'

Content of the single realm of both transcendence and immanence of deity is found within reality. This Jewish expression of faith depends upon a variety of sources sublime mystery, ${ }^{12}$ divine glory and Jewish tradition (Merkle 1985:viii-ix, 51). According to Merkle (ibid:155ff.), when these sources of reality are established and in place, Heschel is ready to explore the elements antecedent to faith: wonder and awe, indebtedness and praise, remembrance and mitzvah (Merkle ibid:ix-x; 153-217). For Heschel these are the crucial ingredients out of which authentic faith is given birth within the context of God's pathos. This is what distinguishes God from the god of the philosophers. God is not indifferent to creation. It is his handiwork. Humankind is therefore regarded with attributes expressing love, mercy, compassion, grief and anger (cf. Ps 145:9; Heschel 1972b:244-245). Pathos allows for a careful distinction made between realities. On the one hand, those that serve as sources of faith, and on the other hand serve as antecedents to faith (Merkle ibid:218). To that end, humankind is perceived as plunged into the middle of a story that has been unfolding since the beginning of time, because the Bible tells the story of God's anthropology in the first instance, and is man's theology in the second (Heschel ibid:412). It is part of the story of what God is about within creation and, particularly, this earth and humankind. From a religious perspective, it is the story of God unfolding his plan of creation, reconciliation and renewal. More specifically, the Christian story sees the accomplishment of this through his Son, culminating in a new heaven and earth populated by the faithful.

\section{Antecedents of faith}

Heschel's writings seemingly contradict themselves when he refers to an experience and act as antecedent to faith in one place and, in another, as an aspect or element of faith.

11.'Mankind does not the have the choice of religion and neutrality. Irreligion is not an opiate but poison' (Heschel 1978:107).

12. Mystery in the sense of that which is beyond human ken rather than some esoteric insights limited to the initiated.
Merkle (1985:219) explains this by distinguishing between faith's objectivity and subjectivity. Here is no ontological confusion. Faith responds subjectively to $\operatorname{God}^{13}$ in its primary sense, but does not do so to nature and tradition, which are objective sources of faith. Subjectivity negates a conclusion of faith as content. Objectivity, however, allows for that. People are 'wired' for a religious experience that participates in transcendence (Smith 1963:195). ${ }^{14}$

In this light, some antecedents may evoke responses to nature and tradition. That is seen in the sense of a movement towards faith - allowing that the same antecedent may suitably serve as faith's content. Heschel translates this into what may be termed as 'moment' or 'instant' (Heschel 1972a):

We are penetrated by His insight. We cannot think any more as if He were there and we here. He is both there and here. He is not a being, but being in and beyond all beings. (p. 78)

This is a conclusion based upon spiritual insight of religion that brings about a moment when transcendence and immanence meet. The response to this being 'shaken for an instant by the eternal' is a lasting cry emanating, not from emotion, but from the power infused and concludes in one word: God (Heschel ibid:78-79).

Antecedents lead to this moment. Although different commentators such as Merkle and Rothschild comment variously upon the structure of these antecedents, this article will by and large follow the former's structure. The reason being that it systematises the antecedents logically and that the author writes as one deeply involved in Jewish-Christian relations, ${ }^{15}$ and also brings about a valuable Christian perspective to Heschel's writings. This article attempts to give the essence of Heschel's exploration of antecedents, as his treatment of the subject is extensive.

\section{Wonder and awe as antecedents of faith}

Heschel's own structure highlights the conclusion of the process determinative of wonder and awe as radical amazement (Heschel 1972a:11). At times he does equate radical amazement with wonder (Heschel 1972b:45) and so deals with the concepts with some fluidity. Merkle (1985:153), however, chooses to invert the antecedents before its consequence. Though wonder and awe are not traditionally aspects of Jewish faith when nature and tradition are meditated upon; they are of religion (Merkle ibid:219), because both evoke a response to God. Both are of course closely related, but nevertheless distinguishable as a single experience of reality (Merkle ibid:153). Both antecedents 'are moments charged with transcendent meaning, moments in which we wrestle with life's ultimate question and in which a sense of indebtedness wells up within our souls' (Merkle ibid:174).

\section{God may be subject and object (Heschel 1959:5).}

14.To get the point across, Heschel (1959:8) illustrates this graphically: knocking your head against a wall as one way to establish 'the realness of reality [...] outside of the mind'.

15.John Merkle of the College of Saint Benedict and Saint John's University serves the Jay Phillips Center as director and a key figure in Christian and Jewish dialogue (CSBSJU n.d.). 
Nature and tradition give rise to wonder and awe as its mysteries are probed through meditation. In this sense, God is not a scientific problem, but the One who surpasses nature (Heschel 1972b:102). This response to meditation is religious and not particularly incumbent upon the Jewish faith or any other faith for that matter. However, wonder and awe do evoke degrees of response to what eventually is termed as deity. In this regard, they precede the emergence of faith, but upon emergence follow the consequence of its fixation (Merkle 1985:219). God does not displace the antecedent of wonder and awe - rather they serve to bring to consciousness the realities of his handiwork and plan.

A degree of awe is called 'a categorical imperative' (Heschel 1972a:27). Related to wisdom (Ps 111:10; Job 28:28), it affects living, the enjoyment of the earth resources, its beauty as well as recognises the sanctity of life and so on (Merkle 1985:170). In this sense, Heschel illustrates that to understand this world one has to seek the foundation which is God (Merkle ibid:170), and so he extends beyond the concept of mere fascination (Merkle ibid:167). Realities reveal God and so serve as sources of faith. Heschel's fixation upon the prophets (Heschel 1962) illustrates this.

Hand in hand with awe is the awareness of wonder in the fact that all of creation is indebted to God. This approach deeply affects any stake of ownership and claim humankind might presume upon. Wonder fixates upon God in a relational sense of Creator and created. Within this soil, faith becomes rooted (Merkle 1985:166). Creation, in this sense of actuated reality, alludes to transcendent reality and awareness of the divine (Merkle ibid:154).

Heschel applies this meditation by linking it to the concept of indebtedness. Humankind asserts its freedom and dominance evident in how it regards the earth's natural resources. The cause for manipulation is even escalating to become threats of war - antithetic to an attitude conducive to religious faith (Merkle 1985:154), for '[a]wareness of the divine begins with wonder' (Heschel 1972b:46). Without wonder, humankind is degraded to levels of chattel and number valued in terms of existence and profit-making (Merkle ibid:155). To stop there is to accept and not seek beyond that (Merkle ibid:155). Only then, when the world is not taken for granted, humankind can face reality, which leads to understanding. 'The world is not just here. It shocks us into amazement' (quoted in Merkle ibid:156, fn. 19). This regard for a composite reality explains something of the radical amazement Heschel refers to.

Radical amazement serves as the entrance into a state of knowledge that allows science and philosophy to exist, but to go beyond acceptance of material reality - pushes beyond the reality experience for answers. Questions are therefore not necessarily followed by answers, for they probe the mystery of ultimate source going beyond the limitations of self-sufficiency (Merkle 1985:156-157). Heschel (1972b:98) sees doubt as a fostering of own ideas, whilst wonder is an act in which the mind confronts the universe - confirming the biblical perspective of facing reality.
In conclusion, the question is of course how to deal with a question of 'what to do with the feelings of faith, awe, wonder or fear' (Heschel 1972b:112, 162) as the mystery of living is faced as fact and experience. It concludes with either a dead emptiness or with a heart that seeks God (Heschel ibid:113) - pointing and leading to worship, in the sense that humankind is consciously brought to consider reality in its most ultimate sense within the moment beyond self or a moment of encounter (Heschel ibid:114ff.).

\section{Indebtedness and praise}

Indebtedness awakens within the person who comprehends that this world's foundations are not to be found within a closed material system. This sense of limited comprehension directs the mind to extend its apprehension beyond it and arises from worship. 'Transcendence is the test of religious truth. A genuine insight rends the enclosure of the heart and bestows on man the power to rise above himself' (Heschel 1972b:162). Whilst worship evokes a perception of indebtedness and praise (Merkle 1985:173), it is particular awe, wonder and fear that awaken the soul to indebtedness (Heschel ibid:112).

Indebtedness impacts upon the way life is regarded and living is viewed. It demands a response at all levels, in particular one that expresses itself in religious overtones. In the light of the splendour of God, humankind's inadequacy leads to embarrassment (Merkle 1985:179-180). Herein is the beginning of a formulating of the question: What does God desire? (Heschel 1972b:246-247). Behind it lies divine pathos, for not only is humankind aware of the splendour of God, it is also the conscious of the one motive for divine pathos: 'The divine need for human righteousness' (Heschel ibid:244-245). As humankind seek God, so God seeks them with a sense of expectancy, for there is the breath of God in every human being (Heschel ibid:251).

Indebtedness at some stage transcends the categorical structures of this world to become a presupposition of faith (Merkle 1985:185). A Jewish perspective is that conscience plays a role in this as it becomes sensitised through the Torah and the prophets (Merkle ibid:183). Humankind realises that to be is not necessarily to claim ownership, but to recognise the indebtedness of all of creation to answer divine claims and concerns (Merkle ibid:178). Of necessity this must therefore encapsulate all events of history - good and evil, creation and destruction - and must translate into worship and dependence, glory and search for righteousness (Merkle ibid:183) as well as an acceptance that seeks the meaning of existence within the realm of faith. Faith presupposes indebtedness to God and is therefore a response to God (Merkle ibid:185). As Merkle (ibid:219-220) explains, it is antecedent to faith, for some it prepares their sense of indebtedness to lead to a consciousness to God.

Praise is elicited from seeing the earth as the Lord's and recognising his glory displayed with accompanying indebtedness (Merkle 1985:185, 187). Indebtedness is not the singular experience of Jews, but of all people. Therefore, 
praise is not seen as being exclusive to one particular people - though the object of praise would be a matter of choice. However, not to be discerning is to lapse into superstition (Heschel 1972a:159). For Israel, worship was part of the community and commonly expressed in vocal and musical forms, but they never did so individually (Merkle ibid:187). For the Chasidic community, this would sometimes translate into involuntarily dancing and joy.

Heschel sees a deeper cause accompanying praise than only a concern for God: God's concern for creation and for humankind, a feeling with God (Merkle 1985:186). Love and prayer are closely associated with praise. Praise finds its origination from that relationship with God leading to knowledge, insight, wisdom and more (Merkle ibid:188, 189) and prayer in the insight that humankind coexists with God. Praise raises the awareness of religious insight for humankind and so precedes faith, for praise may be unknowing and without direction. It is, however, faith's essential and climactic moment (Merkle ibid:190), arising from response to the glory of God, which as an antecedent may give rise to faith. Faith may express as faithful response to glory, but it may also become a moment in which a person may commune with God and his glory (Merkle ibid:190).

\section{Remembrance and Mitsvah}

Authentic faith is distinguished from faith which is tragically wrong (Heschel 1972a:160). Jewish faith is remembrance of historic events and experience (Merkle 1985:193), such as found in the voice which uttered the Shema: 'Hear, O Israel' (Heschel ibid:161). Sacred events accumulated over centuries constitute memory and a source of faith as it recounts ancient moments (Heschel ibid:162). Traditional moments become a composite of those of present reality, and responses to new moments become loyalty to the event and response (Heschel ibid:165). Janz (2004:190) similarly seeks a transcendent moment he calls an 'ideal actuality'. Whereas Heschel allows for more latitude, this moment of actuality is carefully defined by Janz to, for instance, exclude subjective persuasion - an ideal he tries to avoid but supports in the process of his model (Potgieter 2013a).

Response in relation to God translates into faith and avoids reasoned dogma as memory responses that idolise faith. Heschel regards science as integrating the known with the unknown, and faith as integrating the unknown with the divine (Heschel 1972a:171). In this sense, God's plan of suffering is explained in terms of the necessity for Israel to atone for humankind's sins. Thus, remembrance keeps the focus on God and not on faith, which would be idolatry for '[i]t is essential that God believe in man as that man should believe in God' (Heschel ibid:174-175) - a communion shared.

Mitsvot is plural and mitzvah singular and encompass the exposition of the Torah, relating all possible nuances to the 613 Mitsvot (commandments). ${ }^{16}$ Here, the indebtedness to

16.See, for instance, Chafetz Chayim (1990). On the other hand, Heilman (1998:81ff.) finds it problematic to define present Jewish identity, pointing out the differences of terms such as Jewish, Israeli, and even more so when culturally paired, for example. Jewish American and Jewish and Israeli with the additional dynamic of movement from one defined Jewish world to another on a daily basis (Heilman ibid:83)
God is expressed. This is done by expressing God in sacred deeds 'where earth and heaven meet' (Heschel 1972b:353). Heschel addresses the implied legalism, relating living with mitsvot and living giving rise to song and joy as expressed in Scripture. Underlying mitsvot is the fact that explanations do not substitute for the holy (Heschel ibid:354). In this sense, living may express prayer, discovery of God's presence and so on, to finally climax in meeting with the holy and possible ecstasy (Heschel ibid:355, 357-360).

Mitsvot may lead to faith for one, whilst another reaches the threshold of faith through a leap of faith (Merkle 1985:207, 210). Conversely, a mitzvah may simply be regarded as a good deed of some value and not be a sign of faith in God, and so be antecedent of faithfulness. The remarkable thing that Heschel focuses on is that it is not personal salvation that is aimed at, but universal redemption freeing a world from the demonic (Merkle ibid:215-215). To accomplish this redemption, mitsvot is a partnership in process - not a once off event. Messiah, as redeemer, reveals the 'Messiah in us' (Merkle ibid:238) for God and man aid one another. Man is a divine need. Divine omnipotence is therefore foreign to Jewish thought, for God cannot violate human freedom. God may be considered to be concealed, and whilst mitsvot reveals God, it may only be as an antecedent of faithfulness.

\section{A legitimate and living faith in God from a Christian perspective}

There is little doubt that Christianity inherited the notion that God is not only the creator of the heavens and the earth, but also a caring God (Kasimov 1981:432, 433). He is not the unmoved mover of Aristotle, but expressing divine pathos. Together with Heschel, Christians hold that religion is a response to God (Heschel 1972a:175) ${ }^{17}$ in which moral and intellectual training leads to acquiring faith in God (Heschel 1966:131). Louis Berkhof (1873-1957; 1979:106109) sees the seat of religion as located in the intellect, will, emotions and the heart. What impresses upon this seat is revelation and, from Heschel's perspective, the awareness that humankind is part and parcel of reality in a mysterious relationship to humankind regarded, for instance with awe and wonder. How this relationship is interpreted in its impact is explained above in the movement of faith. For Berkhof, this interpretation would be tantamount to the origin of religion. Keith Ward, for instance will see progress from the seat of religion as leading to distinctive religious expressions to express a soft panentheism reflective of, and an accommodation of modern science (Potgieter 2002). Berkhof, holding to a reformed position of the Christian faith, holds to a prolegomena that distinguishes between external and internal revelation. It is within the latter that he suggests his antecedents: human understanding, speculative reason, devout feeling or religious intuition, moral consciousness, faith the proper and the ground of faith (Berkhof ibid: 170-186).

17.Strengthened by his comment that "Christianity and Islam, far from being accidents of history or purely human phenomena, are regarded as part of God's design for the redemption of all men' (Heschel 1966:132). A search for God is humankind's quest (Heschel 1954). 
Rather than pursuing dynamic faith expressing itself, Berkhof pursues the consequence of a relationship between external and internal revelation, whilst acknowledging that revelation is simply not revelation until it is brought home to the heart of man in faith (Berkhof 1979:170; cf. Heschel 1967:137). Something of Heschel's settlement within the heart of the dynamic of faith is hinted to by Berkhof (ibid:170) who holds that, as a person interacts with revelation, God settles faith within the heart as consequence. Although this position may be developed in Berkhof's theology, he follows the intellectual route of tracing his antecedents, without the intensity of Heschel's continual interaction with the subjective and God as subject brought about by his depth theology.

The impression is that Christian faith needs to be distinct through its expression of the immanent Christ, which separates it from other religions. Such a relational approach seems to maintain something of the mystery of God, before or after creedal formulations, that Christians deal with in meeting divine revelation in nature and person ( $\mathrm{Rm} \mathrm{16:25)}$ - expressing awe and radical amazement. Heschel (1967:140) would add that without the outburst of prophetic demands coming upon us again and again, religion may become fossilised.

\section{Conclusion}

In conclusion, this article highlights the contribution that Rabbi Heschel made to the understanding of the subjective development of faith from antecedents to conclude with a living faith relation with God. Berkhof does the same, but follows the more objective route. A marriage of the two could only enrich the faith of the faithful and thus maintain its distinctive in both Judaism and Christianity. We need to address our feebleness in agreement, and not so much on what is so intensely disagreed on (Heschel 1967:139).

\section{Acknowledgements Competing interests}

The author declares that he has no financial or personal relationship(s) that may have inappropriately influenced him in writing this article.

\section{References}

Berkhof, L., 1979, Introduction to systematic theology, Baker Book House, Grand Rapids.

Breslow, A., 1970, 'Thickness, cross-sectional areas and depth invasion in the prognosis of cutaneous melanoma', Annals of Surgery 172(5), 902-908. http:// dx.doi.org/10.1097/00000658-197011000-00017

Chafetz Chayim, 1990, The concise book of Mitzvoth: The commandments which can be observed today, compiled by the Chafetz Chayim, transl. C. Wengrove, Feldheim, Jerusalem/New York. (The Torah Classics Library).

Cohen, J., 1908, Prolegomena to a complete exposition of theism, Swan Sonnenschein $\&$ Co, Bloomsbury.

College of Saint Benedict Saint John's University (CSBSJU), n.d., Jay Phillips Center for Interfaith Learning: Personnel, viewed 15 September 2012, from http://www. csbsju.edu/Jay-Phillips-Center/Personnel.htm

Cross, F.L. (ed.), 1977, The Oxford Dictionary of the Christian Church, Oxford University Press, Oxford.
Friedman, M., 1976, 'Divine need and human wonder: The philosophy of Abraham J. Heschel', Judaism 25(1), 65-78.

Green, A., 1997, 'Menahem Mendel of Kotsk', in R.J. Zwi Werblowsky \& G. Wigoder (eds.), The Oxford Dictionary of Jewish religion, pp. 453-454, Oxford University Press, New York/Oxford.

Guthrie, D., 1981, New Testament theology, InterVarsity Press, Leicester.

Hajdu, A. \& Mazor, Y., 1971, 'Fr-Ha', in C. Roth \& G. Wigoder (eds.), Encyclopaedia Judaica, vol. 7, pp. 1390-1433, Keter Publishing House, Jerusalem.

Hartman, D., 1997, 'Foreword', in F.A. Rothschild (ed.), Between God and man: An interpretation of Judaism, pp. 1-3, Free Press Paperbacks - A division of Simon $\&$ Schuster, New York.

Heilman, S.C, 1998, 'Building Jewish identity for tomorrow: Possible or not?', in E. Krausz \& G. Tulea (eds.), Jewish survival. The identity problem at close of the twentieth century, pp. 77-86, Transaction Publishers, New Brunswick.

Hellwig, M.K., 1985, 'Foreword', in J.C. Merkle (ed.), The Genesis of faith: The depth theology of Abraham Joshua Heschel, p. xi, MacMillan Publishing Company/ Collier Macmillan Publishers, New York/London.

Heschel, A.J., 1954, Man's quest for God: Studies in prayer and symbolism, Charles Scribner's Sons, New York.

Heschel, A.J., 1959, 'Prayer and theological discipline', Union Theological Seminary Quarterly Review 14(4), 3-8.

Heschel, A.J., 1962, The prophets, Harper \& Row/The Jewish Publication Society of America, New York.

Heschel, A.J., 1966, 'No religion is an island', Union Theological Seminary Quarterly Review 21(2, 1), 117-134.

Heschel, A.J., 1967, 'What we might do together', Religious Education Association 62(2), 133-140. http://dx.doi.org/10.1080/0034408670620211

Heschel, A.J., 1972a, Man is not alone: A philosophy of religion, Octagon Books - A division of Farrar, Straus \& Giroux, New York.

Heschel, A.J., 1972b, God in search of man: A philosophy of religion, Octagon Books A division of Farrar, Straus \& Giroux, New York.

Heschel, A.J., 1978, The earth is the Lord's: The inner world of the Jew in east Europe, Farrar, Straus \& Giroux, New York.

Janz, P.D., 2004, God, the mind's desire, reference, reason and Christian thinking, Cambridge University Press, Cambridge. http://dx.doi.org/10.1017/CBO9780511487767

Jospe, A., 1971, 'Lek-Mil', in C. Roth \& G. Wigoder (eds.), Encyclopaedia Judaica, vol. 11, pp. 1329, Keter Publishing House, Jerusalem.

Kasimov, H., 1981, 'Abraham Joshua Heschel and interreligious dialogue', Journal of Ecumenical Studies 18(3), 423-434.

Kirkus, 2012, Kirkus Review. Between God and man: The thought of Abraham J. Heschel, viewed 12 September 2012, from https://www.kirkusreviews.com/bookreviews/fritz-a-ed-rothschild/between-god-and-man-the-thought-of-abraham-jhe/\#review

Lewis, C.S., 1955, Surprised by joy: The shape of my early life, Geoffrey Bles, London.

Mendelssohn, M., Lessing, G. \& Lavator, J.C., 1971, 'Lek-Mil', in C. Roth \& G. Wigoder (eds.), Encyclopaedia Judaica, vol. 11, pp. 1729-1786. Keter Publishing House, Jerusalem.

Merkle, J.C., 1985, The Genesis of faith: The depth theology of Abraham Joshua Heschel, MacMillan Publishing Company/Collier Macmillan Publishers, New York/ Heschel,
London.

O'Leary, P., 2006, Depth theology: Poems, contemporary poetry series, The University of Georgia Press, Athens/London.

Potgieter, R.M., 2002, 'Keith Ward and Panentheism. An evaluation of Keith Ward's Panentheism as a step towards a model for a Christian interpretation of cosmology', PhD thesis, School of Theology, North-West University.

Potgieter R., 2013a, 'A brief critical approach to Janz's Penultimate Space Model to authenticate experience with the transcendental from a Christian perspective', In die Skriflig/In Luce Verbi 47(1), Art. \#107, 8 pages. doi: 10.4102/ids.v47i1.107

Potgieter, R., 2013b, 'Keith Ward's soft panentheism', In die Skriflig/In Luce Verbi 47(1), Art. \#581, 9 pages. doi: 10.4102/ids.v47i1.581

QuoteDB n.d., Jedi Master Yoda, viewed 30 August 2012, from http://www.quotedb. com/quotes/42

Rothschild, F.A. (ed.), 1965, Between God and man. An interpretation of Judaism. From the writings of Abraham J. Heschel. Selected, edited, and introduced by Fritz A. Rothschild, Free Press Paperbacks - A division of Simon \& Schuster, New York.

Russell, B., 1945, A history of Western philosophy: Its connection with political and social circumstances from the earliest times to the present day, Simon \& Schuster, New York.

Schellenberg, J.L., 2005, Prolegomena to a philosophy of religion, Cornell University Press, New York.

Scholem, G., 1971, 'B', in C. Roth \& G. Wigoder (eds.), Encyclopaedia Judaica, vol. 4, pp. 6-7. Keter Publishing House, Jerusalem.

Smith, W.C., 1963, The meaning and end of religion, a new approach to the religious traditions of mankind, The Macmillan Company, New York.

Wikipedia, n.d., Qualitative marketing research - redirected from Depth interview, viewed 20 August 2012, from http://en.wikipedia.org/wiki/Depth_interview 